\title{
COMMENTARY
}

\section{Youth is wasted on the young}

Marc S Penn*, Martiza E Mayorga and Feng Dong

\begin{abstract}
Amphibians and zebrafish are able to regenerate lost myocardial tissue without loss of cardiac function; whereas mammals, in response to myocardial injury, develop scar and lose cardiac function. This dichotomy of response has been thought to be due to the fact that adult mammalian cardiac myocytes are multinucleated and have limited proliferative capacity. Neonatal mammalian cardiac myocytes do have a limited capacity to proliferate. What has been unknown is whether this limited proliferative capacity is associated with the ability to regenerate myocardial tissue soon after birth. Recently, it has been demonstrated that 1-day-old neonatal mice do have the ability to regenerate resected cardiac tissue, and that the capacity to regenerate cardiac tissue is lost by 7 days after birth. The present commentary reviews these results and attempts to offer perspective as to how these important findings relate to current and future strategies to prevent and treat cardiac dysfunction in clinical populations.
\end{abstract}

Following acute myocardial infarction, the human heart can lose over a billion cardiac myocytes. The injured tissue undergoes fibrosis, leading to significant loss of contractile function, adverse left ventricular remodeling and ultimately chronic heart failure. Adult mammalian cardiac myocytes are multinucleated and it has been well documented that only a limited number of cardiac myocytes enter the cell cycle following myocardial repair [1]. Scientists at the bench have known for decades that cardiac myocytes isolated from adult mammalian myocardium do not enter the cell cycle and actively divide, whereas cardiac myocytes from neonatal myocardium do have a limited capacity to divide in culture. The limited proliferative capacity of adult cardiac myocytes correlates with the limited capacity of the adult myocardium to

*Correspondence: marc.s.penn@gmail.com

Skirball Laboratory for Cardiovascular Cellular Therapeutics, Cleveland Clinic, NE3, 9500 Euclid Avenue, Cleveland, OH 44195, USA regenerate itself following acute myocardial infarction, and is in distinct contrast to the regenerative capacity of the myocardium in lower life forms, including zebrafish [2].

The recent publication by Porrello and colleagues sought to answer the question of whether the neonatal mammalian heart has the capacity for regeneration that is lost with aging [3]. To answer this question they resected the apex of the hearts of 1-day-old neonatal mice and found that the myocardium does regenerate. The regenerative process is accompanied by proliferation of cardiac myocytes that peaked at 7 days after resection. By 21 days after resection the apex of experimental animals was indistinguishable from that of sham animals, without any evidence of significant scar. Furthermore, cardiac function and chamber dimensions were similarly unchanged between experimental and sham-treated animals. In distinct contrast, apical resection in 7-day-old mice did not lead to cardiac myocyte proliferation or regeneration of the lost apical tissue. Rather, the apex in the 7-day-old mice was markedly fibrotic, suggesting that the regenerative capacity of neonatal myocardium is lost within the first week of life.

The ultimate issue is identifying the mechanism(s) behind myocardial regeneration in 1-day-old mice that is lost with aging, and whether this mechanism(s) can be re-established to achieve clinically meaningful regeneration in patients with left ventricular dysfunction. Figure 1 schematizes multiple potential mechanisms associated with myocardial repair that could be, and arguably need to be, investigated.

Since the seminal work of Orlic and colleagues $[4,5]$, the field of cardiac regeneration has demonstrated the potential to induce cardiac repair using adult stem cells; however, it is unlikely that a significant mechanism of the observed benefit is associated with myocardial regeneration. Multiple stem cell populations have been studied and have demonstrated benefit with multiple adult stem cell populations in preclinical studies $[6,7]$ and in clinical populations [8-12]. Furthermore, the elucidation of relevant mechanisms associated with myocardial repair $[13,14]$ has led to novel clinical trials that focus on inducing endogenous repair in the absence of stem cell delivery (Clinicaltrials.gov: CXCL12, NCT01082094, Thymosin $\beta 4$ and NCT01311518). 


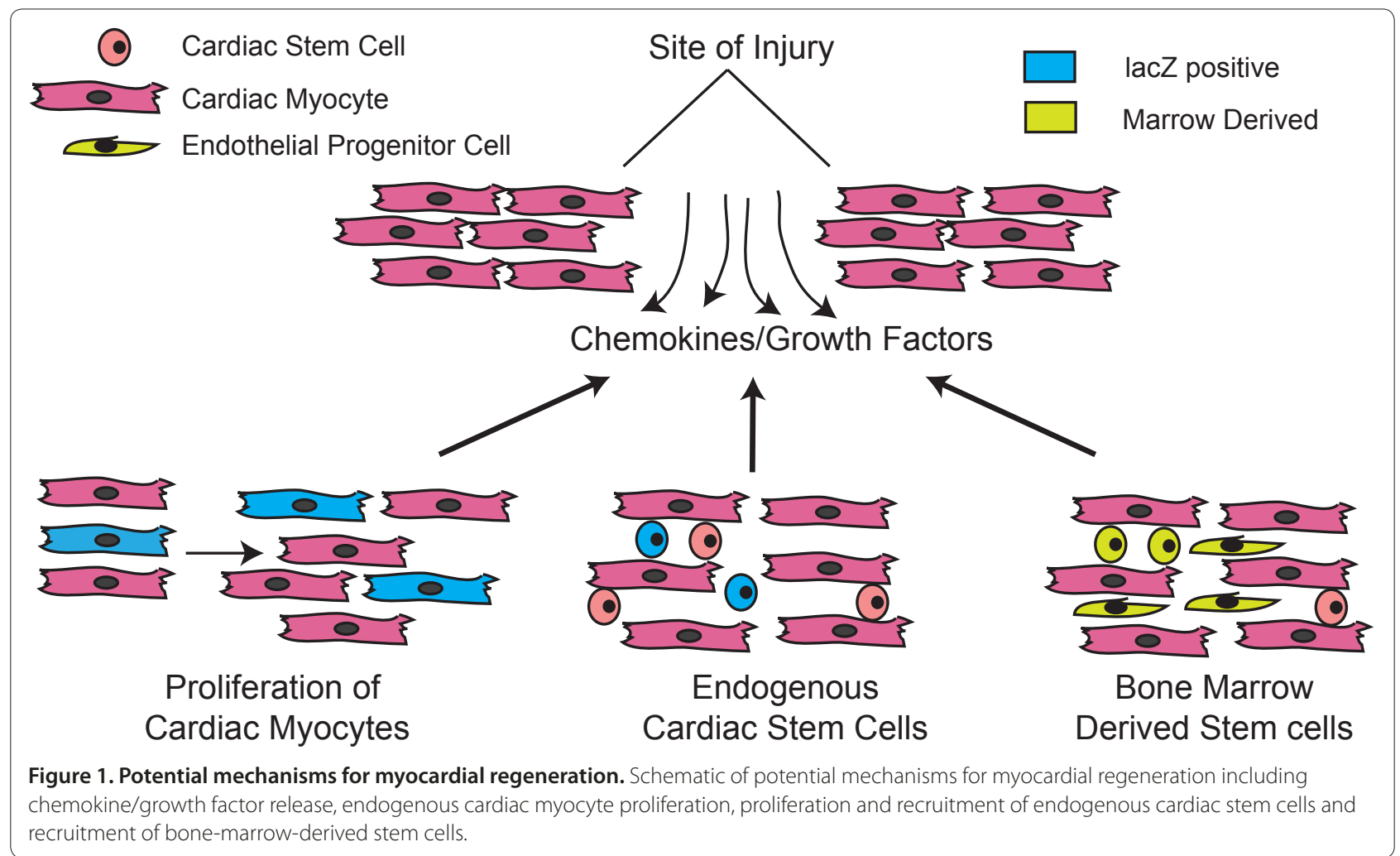

In the study by Porrello and colleagues, the authors attempted to determine whether the cardiac myocytes in the regenerated apical tissue were derived from endogenous cardiac myocytes or a source of progenitor cells [3]. To address this question they cross the $\alpha \mathrm{MHC}$ MerCreMer mouse with the Rosa26-lacZ reporter mouse. The mice were treated with a single dose of tamoxifen at birth. The dosing of tamoxifen led to chimeric cardiac myocytes with a specific percentage being lacZ-positive. If the apex was regenerated from endogenous cardiac myocytes, then the regenerated tissue should have the same percentage of lacZ-positive cardiac myocytes; whereas if the tissue was regenerated from a progenitor pool, then the apex would have a higher percentage of lacZ-negative cardiac myocytes since the tamoxifen would not have activated the $\alpha \mathrm{MHC}$ MerCreMer promoter in these cells. The data nicely demonstrate that the regenerated apex had the same proportion of lacZ-positive cardiac myocytes as the endogenous myocardium [3], suggesting that the regenerated tissue was derived from endogenous cardiac myocytes. While this may be accurate, what is not taken into account is that the $\alpha \mathrm{MHC}-\mathrm{MerCreMer}$ promoter is activated in cardiac stem cells. These mice therefore probably have a chimera of lacZ-positive and lacZnegative cardiac stem cells from which the cardiac myocytes in the regenerated apex could have been derived.
Regardless, the findings of the paper are relevant since there is little evidence that adult cardiac stem cells can regenerate cardiac myocytes [15].

Consistent with the observations by Porrello and colleagues with respect to myocardial regeneration, stem cell function and endogenous myocardial repair are lost with aging. We recently demonstrated that cardiac myocyte hypertrophy in response to pressure overload is age dependent. We further demonstrated that aging leads to a decline in the generation of bone-marrow-derived cardiac stem cells, and that the effects of aging on cardiac myocyte hypertrophy could be reversed by transplantation of young bone marrow into aged mice [16].

The loss of cardiac myocyte regeneration and repair with aging may help explain the rarity of cardiac tumors. Such observations suggest that dissecting the cardiac regenerative and reparative mechanisms lost with aging that have relevance to tumor suppression could yield important targets for future therapeutic approaches. One such example is our recent finding that downregulation of the tumor suppressor protein disabled-2 results in significantly improved stem-cell-based cardiac repair [17].

In summary, the study by Porrello and colleagues demonstrates that the complete regeneration of myocardial tissue is possible in mammals [3]. This observation is important because we now know that myocardial 
regeneration is a natural process in mammals; and if we can define the associated mechanisms, and determine how these mechanisms are modulated by aging, new therapeutic strategies targeted at myocardial regeneration should be possible.

\section{Competing interests}

The authors declare that they have no competing interests.

Published: 18 May 2011

\section{References}

1. Beltrami AP, Urbanek K, Kajstura J, Yan SM, Finato N, Bussani R, Nadal-Ginard B, Silvestri F, Leri A, Beltrami CA, Anversa P: Evidence that human cardiac myocytes divide after myocardial infarction. NEngl J Med 2001, 344:1750-1757.

2. Poss KD, Wilson LG, Keating MT: Heart regeneration in zebrafish. Science 2002, 298:2188-2190.

3. Porrello ER, Mahmoud Al, Simpson E, Hill JA, Richardson JA, Olson EN, Sadek HA: Transient regenerative potential of the neonatal mouse heart. Science 2011, 331:1078-1080.

4. Orlic D, Kajstura J, Chimenti S, Jakoniuk I, Anderson SM, Li B, Pickel J, McKay R, Nadal-Ginard B, Bodine DM, Leri A, Anversa P: Bone marrow cells regenerate infarcted myocardium. Nature 2001, 410:701-705.

5. Orlic D, Kajstura J, Chimenti S, Limana F, Jakoniuk I, Quaini F, Nadal-Ginard B, Bodine DM, Leri A, Anversa P: Mobilized bone marrow cells repair the infarcted heart, improving function and survival. Proc Natl Acad Sci U S A 2001, 98:10344-10349.

6. Van't HW, Mal N, Huang Y, Zhang M, Popovic Z, Forudi F, Deans R, Penn MS: Direct delivery of syngeneic and allogeneic large-scale expanded multipotent adult progenitor cells improves cardiac function after myocardial infarct. Cytotherapy 2007, 9:477-487.

7. Zhang M, Mal N, Kiedrowski M, Chacko M, Askari AT, Popovic ZB, Koc ON, Penn MS: SDF-1 expression by mesenchymal stem cells results in trophic support of cardiac myocytes after myocardial infarction. FASEB J 2007, 21:3197-3207

8. Willerson JT, Perin EC, Ellis SG, Pepine CJ, Henry TD, Zhao DX, Lai D, Penn MS, Byrne BJ, Silva G, Gee A, Traverse JH, Hatzopoulos AK, Forder JR, Martin D, Kronenberg M, Taylor DA, Cogle CR, Baraniuk S, Westbrook L, Sayre SL, Vojvodic RW, Gordon DJ, Skarlatos SI, Moye LA, Simari RD: Intramyocardial injection of autologous bone marrow mononuclear cells for patients with chronic ischemic heart disease and left ventricular dysfunction (First Mononuclear Cells injected in the US [FOCUS]): rationale and design. Am Heart J 2010, 160:215-223.

9. Traverse JH, Henry TD, Vaughn DE, Ellis SG, Pepine CJ, Willerson JT, Zhao DX, Piller LB, Penn MS, Byrne BJ, Perin EC, Gee AP, Hatzopoulos AK, McKenna DH,
Forder JR, Taylor DA, Cogle CR, Olson RE, Jorgenson BC, Sayre SL, Vojvodic RW, Gordon DJ, Skarlatos SI, Moye' LA, Simari RD: Rationale and design for TIME: a phase II, randomized, double-blind, placebo-controlled pilot trial evaluating the safety and effect of timing of administration of bone marrow mononuclear cells after acute myocardial infarction. Am Heart $\rfloor$ 2009, 158:356-363.

10. Schachinger V, Erbs S, Elsasser A, Haberbosch W, Hambrecht R, Holschermann H, Yu J, Corti R, Mathey DG, Hamm CW, Suselbeck T, Assmus B, Tonn T, Dimmeler S, Zeiher AM: Intracoronary bone marrow-derived progenitor cells in acute myocardial infarction. N Engl J Med 2006, 355:1210-1221.

11. Assmus B, Fischer-Rasokat U, Honold J, Seeger FH, Fichtlscherer S, Tonn T, Seifried E, Schachinger V, Dimmeler S, Zeiher AM: Transcoronary transplantation of functionally competent BMCs is associated with a decrease in natriuretic peptide serum levels and improved survival of patients with chronic postinfarction heart failure: results of the TOPCARECHD Registry. Circ Res 2007, 100:1234-1241.

12. Losordo DW, Schatz RA, White CJ, Udelson JE, Veereshwarayya V, Durgin M, Poh KK, Weinstein R, Kearney M, Chaudhry M, Burg A, Eaton L, Heyd L, Thorne T, Shturman L, Hoffmeister P, Story K, Zak V, Dowling D, Traverse JH, Olson RE, Flanagan J, Sodano D, Murayama T, Kawamoto A, Kusano KF, Wollins J, Welt F, Shah P, Soukas P, et al:: Intramyocardial transplantation of autologous $\mathrm{CD}_{4}{ }^{+}$stem cells for intractable angina: a phase I//la double-blind randomized controlled trial. Circulation 2007, 115:3165-3172.

13. Askari A, Unzek S, Popovic ZB, Goldman CK, Forudi F, kiedrowski M, Rovner A Ellis SG, Thomas JD, DiCorleto PE, Topol EJ, Penn MS: Effect of stromal-cellderived factor-1 on stem cell homing and tissue regeneration in ischemic cardiomyopathy. Lancet 2003, 362:697-703.

14. Bock-Marquette I, Saxena A, White MD, Dimaio JM, Srivastava D: Thymosin $\beta 4$ activates integrin-linked kinase and promotes cardiac cell migration, survival and cardiac repair. Nature 2004, 432:466-472.

15. Unzek S, Zhang M, Mal N, Mills WR, laurita KR, Penn MS: SDF-1 recruits cardiac stem cell like cells that depolarize in vivo. Cell Transplant 2007, 16:879-886.

16. Sopko NA, Turturice BA, Becker ME, Brown CR, Dong F, Popovic ZB, Penn MS: Bone marrow support of the heart in pressure overload is lost with aging. PLOS ONE 2010, 5:e15187.

17. Mayorga ME, Dong F, Sundararaman S, Huang Y, Jiang Y, Howe PH, Penn MS: Central role for disabled-2 in mesenchymal stem cardiac protein expression and functional consequences after engraftment in acute myocardial infarction. Stem Cells Dev 2011, 20:681-693.

doi:10.1186/scrt65

Cite this article as: Penn MS, et al:: Youth is wasted on the young. Stem Cell Research \& Therapy 2011, 2:24. 